\title{
Information of Mohammad Yousuf Moshi about Governance Structure of Bukhara Khani and Positions from the 16th to $18^{\text {th }}$
}

\author{
Mohammad Geraili Kerapi* \\ Academy of Sciences, Institute for Humanities, Khorog, The Republic of Tajikistan \\ *Corresponding Author Email: m.geraili43@yahoo.com
}

\section{Doi:10.5901/mjss.2016.v7n2s2p187}

\section{Abstract}

\begin{abstract}
Mogim Khani biography written by Mohammad Yousuf Monshi who dedicates to Transoxiania and Bukhara Khani history of the 16 th century and 18, it is one of the most important manuscript sources of middle age, Valuable materials of this work is on the history of Transoxania and Bukhara Khani enjoy a special place. An area dominated by Cumania plain nomads, was a land at the top of Amir Khan who Sunni Muslim faithful performed the next and main role. They had crucial positions in State sovereignty and in the political structure of Transoxania there were other positions that it could be offered, including "Begay Divan was a position they served as advisers and secretaries of state. Butterflies or the peaks of the King" which were flagship in the verdict and other various positions such as, Koukeltash, equerry, secretaries and scribes, and so on could be cited. In general, political and administrative structure of Transoxiania and Bukhara Khani in the 16th century to the 18th and comparing this information with the handwriting and credible source in the accuracy of the contents presented by a researcher is rare and new, the hope is that the attention of historians and researchers interested in the history of Transoxania and Bukhara Khani be mentioned at this juncture.
\end{abstract}

Keywords: Transoxiana, Bukhara, Shaybanids, Oshtokhani, Balkh

\section{Introduction}

Moqim Khani biography written by Mohammad Yousuf Monshi, who dedicates to the history of Transoxiania and Bukhara Khani in the 16th century to the $18^{\text {th }}$, is one of the most important handwritten sources of middle ages which have attracted the opinion of Persian, European and Russian scholars. Valuable materials of his work on the history of Transoxania and Bukhara Khani enjoy a special place. An area dominated by Cumania plain nomads, they were able to base the rule of Shaibanid by disarming Timurid. Transoxiania history, especially this period should be known as starting time which historians reminisce it as Khani time. The land which was at the top of the pyramid of Emir or, this Prince was both the Commander-in-Chief and the lord and a great spiritual, in political life of Transoxiania, Sunni Muslim faithful performed the next and main role. They had crucial positions in State sovereignty and in the political structure of Transoxania there were other positions that it could be offered, including "Begay Divan was a position they served as advisers and secretaries of state. Butterflies or the peaks of the King" which were flagship in the verdict and other various positions such as, Koukeltash, equerry, secretaries and scribes, and so on could be cited. In general, political and administrative structure of Transoxiania and Bukhara Khani in the 16th century to the 18th and comparing this information with the handwriting and credible source in the accuracy of the contents presented by a researcher is rare and new, the hope is that the attention of historians and researchers interested in the history of Transoxania and Bukhara Khani be mentioned at this juncture.

\section{Research Structure}

In every research, a researcher must explain the method of own work how their data is collected. In this study, the method of library or document is used. In this method, the researcher by referring to all sources identified has collected the contents needed and taken notes and in writing research he has used them.

The tool of data collection of the researcher in the library method is all printed documents such as books, encyclopedias and dictionaries, magazines, newspapers, dictionaries, yearbooks, published interviews, research letters, books of scientific conferences, printed texts indexed in databases any source identified in print.

In studies which naturally do not seem to have a library method, researchers are also inevitably the application of its research library method. In this research group, including descriptive, correlational, and experimental and so on, the 
researcher must study literature and history of the problem and case studies. As a result, he should use the library method and he records and maintains the results of his studies at the appropriate tools such as paper, table and form, and maintain and in the end, he must act against their classification and exploitation.

The first step in library research skills is to learn how to use the library; it means that researchers must know how to use papers and to register book characteristics, how to search for books in the library and also computers, and the rules of operation and order the book. To do this it is necessary that by studying the sources and using the experiences of others and also tips of librarians acquire the needed skills which in the research conducted by the researcher all this case has been used. And the result is that the researcher has conducted a thorough investigation.

\section{The Beginning of the Article Text}

There mentioned much information on Bukhara Khani governance structure of the 16th century and the beginning of 18th century in Mogim Khani biography. By bringing this information to define the governance structure in Bukhara Khani help us that we're in a certain degree. During this period, the governance structure is difficult to do, but the rule is inherited from the previous period and as a result, local conditions and demographic political situations have sometimes changed. The commanders of the nomadic tribes are elected to the top governmental positions that it led to increasing nomadic princes.

The history information of Moqim Khani shows that the top position of this time was Khan being the supreme ruler of the state (Monshi, 1956). Under the barbaric, high authority was in the hands of Khan in the State and had been Inheritable. According to the characterstic of Khan it is possible that they elect an individual from children members and by the idea of the court among he was elected as an alternative candidate (Soltanov 2001). At the time Khan had specified tasks that including:

A. Khan like Sardar has the right to monitor all the different territories with provinces and can issue various commands. His task is thus to protect the state from external interference.

B. Khan like major-general can declare war and make peace and pact the peace treaty.

C. To spend rights dialogue with all foreign governments and define the role of government in foreign policy.

D. Khan has the authority to kill and punish his subordinate and to keep order and protect the rights is currently in legislation and other governmental actions.

E. The basic principles that choose Khan, is to the sermon and coinage (the same source).

On Mohammad Yousef Monshi infromation in the government of Sheibani and Oshtorkhani, the Sultans played the major role. Positions of Sultans in the period of Sheibani had Bodaghi Soltani, Mohammad Sultan, Khurram Shah Sultan,Sivenj Muhammad Sultan and others (Monshi, 1956).

Famous Sultans were Oshtorkhanid, the boys of Nadir Mohammad Khan, Khosra Shah Sultan, Bahram Sultan, Qatlaq Mohammad Sultan, Abdolrahman Sulatn, Qasem Mohaamad Sultan, Allah Qoli Sultan and others. During the rule of Oshtorkhanid, the heirs to the throne at all in Balkh and other provinces ruled by which they called Sultans. In governmental State of that time, Emirs occupied a special place known as nomadic tribe who were linked. At the time of the macro installation they were still interested in fortified with descendants of two tribes. In the work of Mohammad Yousuf Monshi, there are mentioned a lot of stories about princes and their role in the political life of the population and the government and what they do. Rebel princes were also like Qara Sultan from the tribe who fought Elchin the long years of anti-government (Symyanof, 1948).

As a result, they suffered in the problems and in the case of adverse Emirs fled from the center of its sovereignty and they went to the tribe and their children. They were trying to incite them against their enemies. In the work of Mohammad Yousuf Monshi the name of the owners which were the owner of this position, it said that one of the most important positions were called Naqib (in Arabic -Leader-General of the tribe) who had ruled the state (Hafez tension, 2207). In 1915 and 1606, Valy Mohammad Khan Nadir, sent Muhammad fifteen-year-old to Balkh Atalyq chose Shah Beik Koukeltash who administrated the government cruelly and he abused inhabitants (Mahmoud Ibn Valy, 2207). About underlying map of Atalyq in the time of ruling, the author has some references (Heravi, 1986).

Famous Ataliq during Oshtorkhanid were Mohammad Bi Ataliq, Imam Qoli Ataliq, Mohammad Jan Haji Ataliq, Khashik Bi Ataliq and Adel Bi Ataliq and others (Monshi, 1956).

In Transoxania, Sunni Muslim faithful performed the next and main role. They had crucial positions in State sovereignty and in the political structure of Transoxania there were other positions that it could be offered. They had large positions in government and people paid more attention from government authorities and other influential office holders. For this reason, rulers in solving the problems of governance and some attacks on its territory with demographic and political life, religious representatives returned to help their government. Now information of Mohammad Yusuf Monshi on 
the fight over Transoxania ruling, Imam Qoli Khan to assist the Grand Vizier Seyyed Hashem will return and by supporting on behalf of him, the first victory is acquired over his uncle Valy Mohammad Khan (Monshi, 1956).

From information of Mohammad Yousuf Monshi, the role of the representatives of religion was so great that in some provinces and places the rule entirely entrusted to them. For example, in Balkh government action directed a representation of the religion, son of Sheikh famous Bukhara, Khajeh Abdevaly Parsaei, and Saleh Khajeh. In Badakhshan, Yarbeik, who was one of dervishes in Samarkand, ruled. About a big role in the life of faith, demography and political news has come in other handwritten sources (Muhammad Ibn Valy, in 2207). In State sovereignty an essential role in our investigations is performed by Divan Beiki (Persian-Turkish-general rule). In appointment to another, Divan Beiki stood in the third row (Barthold, 1997). Tasks of Divan Beiki were after Atalyq in second place, the information of Pazoukhyn after news Russian ambassador was in Bukhara. Divan Beiki also was engaged to accept foreign ambassadors and his escort after Atalyq, became the second person (Simian, 1669). Sometimes by decree of command Khan Divan Beiki, he perfromed other important commands as solving the allowance to war and peace and choosing people the top positions in government and other people (Amin Bukhari, 1991). From the information of Mohammad Yousef Monshi are famous Divan Beik of Bukhara and Balkh, Abdul Rahman, Syvinch Bi, Ali Saeed Bi, Masoum Bi and others (Monshi, 1956).

Other duties being in the work of Mohammad Yousuf Monshi are "Butterfly Chi" (Persian commander Khan), the information of authors is in the third place after Atalyq and Divan Beiki (the same source.), and it is in this way that Mahmoud Ibn Valy (Mahmoud Ibn Valy, 2207) concedes Mohammad Amin Bukhari (Bukhari, 1991). Information of Mohammad Yousuf Monshi to "Butterfly Chi" is to run off some important issues such as governance army's siege of some cities and castles-time protection consultation, governance and other provinces (Monshi, 1956). It also stresses Hafez Tension Bukhari (Bukhari, 1991) Mahmoud Ibn Valy (Ibn Valy, 2207) Mohammad Amin Bukhari (Bukhari, 1991). Mohammad Yousuf Monshi writes in Balkh this task is performed by Tangerberdy, Shakourmyngh, Aouzteymour Qatghan and others (Monshi, 1956).

Another task about which Mohammad Yousuf Monshi writes it is litigation (who fights acquitted and the guilty fights), a complainant has a high ranking in governmental positions. To enforce commands of Khan he had some authorities and also for the execution of commands of Khan he had carte blanche to fix the problems of people and he was an interface between Khan and people to convey people' speaking to people (Symyanof, 1948).

In the 16th and 17th centuries, the complainant in the administration of the state was one of the high ranking officials and apart from other things, he controlled public affairs and sometimes did diplomatic and foreign affairs (Akhmdov, 1948). On the information of Mohammad Yousuf Monshi, in Balkh at the time of Nadir Mohammad Khan the duty of the complaint was performed by Emir, the officer, Mansour Khajeh that Khan sent him as the chairman of the ambassadors to the Shah Jahan to India for friendly relations between the two states (Monshi, 1956). Such information about Mahmoud Ibn Valy that was personally acquainted with the complainant and a lot of time with him was consulted in various fields. The information is also confirmed confirms Mohammad Yousuf Monshi. The words of Mahmoud Ibn Valy Khan before another correspondence is sent, first, he showed to Mansour Khan, then from his control he sent command to the person concerned. According to this author, Mansoor Khajeh was given the task complainant that he ordered government affairs and suppressed insurgents and rebels. Mahmoud Ibn Valy on the task of Mansour Dadkhah and the duty of the ambassador for him informs Shah Jahan, and writes that in the year 1048- 1638 Mansoor Khajeh performed well meeting with India's rulers and the peace treaty efficiently was signed.

In general, a complaint on public affairs had the role of the eighth person is confirmed by Mohammed Amin Bukhari (Mahmoud Ibn Valy, 2207).

The most well-known of the writings of Mohammed Yusuf Monshi were complaints of Balkh and Bukhara in the age of 16-18 Beik Mohammad Dorman, Abdollah Aoutkan Bi and others (Monshi, 1956).

One of ranks in Bukhara Khani, about which the research have been done, was Koukeltash. Koukeltashha in Bukhara Khani governance enjoys macro-level and one of the important places was in his authorities. Now Abdullah Khan Sheibani, inly, selects Koukeltash the ruler of Khorasan, where he reigned for 12 years. Other Koukeltash about whom Mohammad Yousuf Monshi informed was Shah Beg Pouladchi who governor of Transoxiana, Valy Mohammad Khan, gave him Balkh ruling and he entrusted the training of his sons, Imam Qoli Sultan and Nadeer Mohammad Sultan to him. Eventually, he was ruthless and unyielding. Information of Mohammad Yousuf Monshi about the great power Koukeltash was in the State governance and other historians confirm it. Now on the position of Koukeltash in Bukhar thesis about the position and ranking have been said that he was one of the people close to Khan (Monshi, 1956). His task was to get information from all public areas and get information about friends and enemies for Khan and find solutions to fight against the enemies for Khan, etc. (Symyanof, 1948). About Koukeltash role in the book of excerpts "Nosrat Nameh" (Akramov.V, 1967), "Habib Alseir" (Khandmir, 2001) has been said too. In Abdullah Nameh has been 
mentioned that Qanbar Mirza Koukeltash ordered that he should be Ataliq Prince, a child of Khurram Shah Ibn Shaibani Khan in Balkh (Hafez Tension, 2207). The author od Bahr al-Asrar, Amir Mahmoud Ibn Valy, when calling some of Emirs being Koukeltash has called, he writes Koukeltash storm of the teacher and trainer of child princes was Imam Qoli Khan and Nadeerr Mohammad Khan (Ibn Valy, 2207).

The other group running for special commands, and were lower in were tipstaffs. The statements of Mohammad Yousuf Monshi, Tipstaffs were accompanying with them when fighting rulers and they were given the command for which they were run. In the reign, Baqi Mohammad Khan who fought to Safavid dynasty in Khorasan he defeated. A right of tipstaff like a person close to his ruling and his little boys, Imam Qoli Sultan and Nadeerr Mohammed Sultan saved from danger and got them safely to Transoxiana. (Monshi, 1956) Hafiz tension Bukhari (Hafez tension, 2207) Mohammad Ibn Valy (Ibn Valy, 2207) and Mohammad Rafi Ansari (Ansari, 1991). They acknowledge news in this way and say that tipstaffs have uncut from Khan and stay with them and their commands are run without interruption. From sayings of the history of excerpts of Nosrat Nameh when recording, the provinces of tipstaffs ordered that the residents be protected from public plundering and they controlled that spoils of war were be collected in the appointed place. These spoils which the amount is owned partly to the government are sent to the base to collect trophies from the tribute (Akramov.V, 1967). Guesthouse author of Bukhara, Fazlullah Ibn Roozbahan Khonji in charge of Shaibani Khan in 1059, the usher extremes in the collecting tribute from them (Akramov, 1414). Mahmoud Ibn Valy writes that to the task of tipstaff, bringing gifts has been from people to Khan and people sayings were sent to Khan. When Mohammad Khan comes from Balkh to Bukhara in Ramadan 1048, 1639, Imam Qoli Khan welcomes magnificent due to his coming that his tipstaff, Beik Mohammad gives a valuable gift to Nadir Khan. This gift was agile horses and fine clothes and rifles, fifty thousand dinars and other valuables and finally, welcoming tipstaff, Nadeer Mohammed Khan to Imam Qoli Khan donated many gifts (Ibn Valy, 2207).

Other tasks that Mohammad Yousuf Monshi refers to it is "Ayshk Aqabashy", in other words, a great servant of the court that was one of the most important functions in the court, this duty was given to trusted people, and Ayshk Aqabashy who did good deeds. They gave them high ranking of duties as they were in need Ayshk Bashi Qtghan in the fight against Khiva and Aryng Sultan succeeded to bring out them from Bukhara and ultimately did masculinity and after killing Arynk Sultan in 1688 was selected as the ruler of Khorezm ( Monshi, 1956). News about the importance of the role of Mohammad Yousuf Monshi on the role of Ayshk Aqabashy is also acknowledged from other authors that have been mentioned on ranking and positions in the thesis of Bukhari. In Bukhara by efforts of Ayshk Bashi has had the obligation of the court as well as water storage and irrigation of court space and from known Ayshk Bashi at the time of Hamrani, Abdullah Khan Touman Qareh Koul can be said (Akramov.V, 1946). From sayings of Mahmoud Ibn Valy, Ayshk Bashi played the duty of constable in court, and they also participated in offensive combats (Ibn Valy, 2207).

Mohammad Yousuf Monshi has mentioned among the most important task in state ranks the name of Mirakhour. He was one of the trusted men of the ruling and gave him livelihood. When the quarrel was on the fence between the tribe of cheetah, Obeydollah Khan entrusted ruling to two people close to the manger, one of which was Khani Beik Mirakhour (Monshi, 1956). From sayings of Mohammad Yusuf Monshi we can mention to Mirakhour who sometimes other important tasks was given to him, one of the tasks was to protect repelling the enemy's castle, one of whom was Yaqoub Mirakhour(the same source).

News about our author on the important role of Mirkhour is acknowledged by other authors. News of Mahmoud Ibn Valy was Mirakhour who worked in the stables and was great and they had a manager (Ibn Valy, 2207). Hafez Tension Bukhari reports that during the rule of Amir Abdullah Khan the task of Mirakhour, the great, was performed by Emir the first Bi who involved in in actively waging war against enemies large and after him this duty was done by Abdol Samad Bi (Hafez Tension, 2207). From sayings of Mohammad Yusuf Monshi during the rule of governance Oshtorkhani, Mirakhour preserved the important tasks that the examples on travel Nadir Khan from Balkh to Bukhara in the year 1048 of 1639 of between his entourages and senior people were persons like Mirakhour Kangal that Khan on this trip was escorted (Mahmoud Ibn Valy, 2207).

One of the other offices was "Qoush Beiki" and his duty was hunting Sardar of Khani and maintenance of hawk and hunting games. The author writes that they had great trust to Qoush Beiki and other high-level tasks were given to them. For example, for the sake of honesty Qoush Beiki Darwish, Abdullah Khan chose him as a ruler. Qoush Beiki also done political work in special cases that Muhammad Moqim Khan for sympathy on the death of Sobhanqoly Khan like an ambassador Mohammed Qoli sent Qoush Beiki to Bukhara to Obeydollah Khan. In general, Qoush Beiki had a high ranking in governance. For good running off duty, he could go to higher positions which gave the duty of Ataliq to him for honesty in his work that he never took the Nadir Khan and then she chose Termez governor of Balkh province and finally he became Divan Beiki for all province (Mahmoud Ibn Vay, 2207).

Another officer, to whom Mohammad Yousuf Monshi refers, is "Touqsba" which was a known Touqsba of Balkh of 
that hard time from the clan of Alchiq, which was about seven years in office had Balkh province. He had not a good performance and people were plundered and looted by him. Famous princes defeated against him a few times to calm him, but they could not. Then, they sent Mahmoud Bi Ataliq to crack down him (Monshi, 1956). About Toshiba's important positions in the treatise of Bukhari, there are mentioned on ranking and duties that taking away food container for the ruler possessed to him and was also part of the irrigation system (Symyanof, 1948).

Another important task of Atalyq is about the news that Mohammad Yousuf Monshi mentioned. According to him, the task was given to Famous Emirs from Khan for his courage in waging war and openness to Khan (Monshi, 1956). Atalyq on your part sometimes considered himself as an authority and attempted that they did not obey the rule. For example, Atalyq Balkh just never wanted to obey Khan and began to fight against him (the same source). In other authors' works in middle age, this would be referred to the important role of this position. In the reign of Abdullah Khan Sheibani when Abdul Khan Momen was sent to Balkh, Amir Khan Goldi Bi was elected to the position of Ataliq (Amin Bukhari, 1991). Another task which was in the State was "Bakavol". It was the Turkish word meaning a servant to the Great Khan and his duty was to take food on the table, Khan and his princes must first eat (Symyanof, 1948). From the news of Mohammad Yousuf Monshi in Balkh, the duty of Bakavol was performed by Khajim Berdi Ming and in Balkh he had a high ranking and in Balkh was collaborating with never just and he was cruel to the inhabitants of that place where he was killed as a result of the command of Muhammad Mukim Khan (Monshi, 1956). From the news of Mohammad Amin Bukhari were the cases that for the effort and zeal Bokavol they know for higher duty which Arsalan Bokavol Turkman was elected to be honest and well executed (Amin Bukhari, 1991).

Other positions were by the command of "Khanchi" who his work was to makeup table for Khan and dining for guests and he was a senior in high ranking court. In thesis of Bukhari it was mentioned that ordering Khanchi was one of the people close to Khan (Symyanof, 1948).

Some consider the cases of ordering Khanchi as more important that Mahmoud ibn Valy writes that in 1049 nadeer Mohammad Khan sent his close associates, including Saleh Khajeh, ordering Khanchi as ambassador to India. Ordering Khanchi sometimes directed in small groups Khan the military offensive (Mahmoud Ibn Valy, 2207).

Other tasks were "librarian". Librarian performed in the court and Khan in schools, tombs elders on duty. It is the duty of librarians to elect Khan from the news of Mohammad Yousuf Monshi, librarians were trusted to ruling. They had credit and special respect onto Khan. In time of Sobhan Qoli Khan, the ruler of Balkh Saleh Khajeh was set off to India and along with him was a librarian Mullah Mohammad Murad chose escort to accompany him as a person (Monshi, 1956). Librarians but his fundamental task they had other duties. For example, Mirza Ghasem elected a librarian as a chaplain and the librarian, Saleh Rakhshi as the task of leading the court poet and Hassan Beik was a special librarian of Khan (Mahmoud Ibn Valy, 2207). Nadeer Mohammad Khan in Balkh had a large library, which its director was Mahmoud Ibn Valy. Precious books were transcribed there. Another task of the state structure is "the clerk and scribe," and each Khan had his personal secretary. The author of Moqim Khani Monshi biography was secretary for the governor of Balkh Mohammad Khan who has written this work by the order of Khan. He agreed the role of Mohammad Yousuf Monshi in managing data in favor of the holders of this high rank in the country. Apart from its basic tasks, other functions were also performed. Mohammad Yusuf Monshi, who was the special scriber for Khan, such as an ambassador was headed to India (the same source). Generally, the news of Mohammad Yousuf Monshi and comparing with other news about the governance structure of the State testify that in the eras 17 and 18 in Transoxiana there has been ruling the specific administrative structure and the news of the author on these positions is authoritative and reliable news.

\section{Conclusion}

Mogim Khani biography written by Mohammad Yousuf Monshi such as handwritten and authentic reference is as the basis handwritten including important information in historical events of Transoxiana and Bukhara Khani in in the 16th century to the early 18th century which has been written by order of Muhammad Moqim Khan, an autonomous governor of Balkh and written by Mohammad Yousuf Monshi with an artifact prose which is with the accent of Bukhari and a reliable source of historical events mentioned in the rule of Shaibanid and Ashtrkhanyha is in political geography of the region. The exact source of the rare knowledge and its importance, especially my observations when compiling some events has caused great Iranian historians consider to attract European and Russian. Here, by introducing researchers who have translated this work into different languages, we have taken an important step in the introduction of this important historical work and also by introducing different books which have related materials with this biography and is written by researchers on topics related to the Russian and Latin Persian language, the valuable situation of this scarce resource made clear this rare handwriting, and their place in the libraries of Russia and Central Asia, Iran and Europe have been shown and the idea of positive thinkers on the role of the authority in the historiography of the Middle Age and 
Bukhara Khani and Transoxania is quite evident. The importance of this research is that the results can set up some historical events which has been in this era in Transoxania and Khani Gary Bukhara established in countries bordering and which it has been pointed out in less source and paves the way the initial step for researchers who devote themselves to research historical events in Transoxania and Khorasan at this point. The results of this research could solve some historical issues related troubleshooting when writing scientific works in this period too. In this paper, it has been tried that by studying a detailed examination of different sources and precise measurement of the position of significant historic and special place among this period of history we realize that this is an important step for the researchers.

\section{References}

Monshi, M. U. (1956). Moqim Khani biography, translated with an introduction and description of the Tajik language and gestures by Professor II Symyanof. Tashkent.

Monshi, M. U. (1991). Mogim Khani biography, Background and Description of Fereshteh Sarrafan. Tehran. documentary heritage. Iran. Sultanov, T.E.V. (2001). Getting up on white felt, descendants of Genghis. Almata. Dic. Pris.

Symynof, A. A. (1948). the treatise of Bukhara on positions, obligation about Officicals of Bukhara in the middle age. S.V.

Bukhari, H. T. Abdullah Nameh, handwritten East Institute of the Academy of Republic of Uzbekistan. No. 207.

Sharaf al-Din Hussein Qomi, J. A. briefly illuminated Tavarikh with good efforts, in 1981. Tehran. Iran.

Bahr al-Asrar fi virtues Alakhyar, Mahmoud al-Wali. handwritten and photocopied Academy of Sciences of the Republic of Uzbekistan. Issue 7418.

Heravi, M. K. (1985). A letter of views of Naderi votes, by efforts of Mohammed Amin Riahi. Tehran. Iran.

Bukhari, M. A. Ubaidullah a translation of Tajik describing Symyanof A. A, Tashkent.

Bartold, V.V. (1964). celebration in the court of Uzbek Khan, in era 17. Moscow. Novak.

Ambassadors of Paris and Semian Pazoukhim, envoys to Bukhara, Balkh and Aourganj, 1669.

Ansari, M. R. (1991). the command of the kings and explaination and translation 17, A. B. Wil Donav. Tashkent. Fan.

Akhmadov. B. A. the history of Balkh, $p$.

The history of Selection, (1967). Nosrat Nameh, research of critical texts. descriptions and maps. A.M.Akramov. Tashkent.

Khand Mir, Kh. (2001). Habib Alseir, by efforts of Jalaleddin Homaei. 4 volumes. Tehran. Iran.

Ansari, M. R. (1991). by the order of the kings, contento of translation and additions. A.B. Wil Danov. Tashkent. Fan.

Fazlullah Ibn Roozbahan Khonji, hostels of Bukhara. handwritten of number 1414. Leningrad. 